\title{
PENGARUH KEPEMILIKAN MANAJEMEN, JENIS INDUSTRI, DIVERSIFIKASI PRODUK, PROFITABILITAS, DAN UMUR PERUSAHAAN TERHADAP PENGUNGKAPAN MANAJEMEN RISIKO PADA INDUSTRI PERBANKAN DAN MANUFAKTUR
}

\author{
Ulfiana Melani \\ Muh Al Amin \\ Universitas Muhammadiyah Magelang \\ ulfianahh@gmail.com
}

\begin{abstract}
This study aims to examine the effect of management ownership, type of industry, product diversification, profitability, and firm age to risk management disclosure on the annual reports of the companies that listed in BEI 2010-2014. The data of this study is secondary data. Sample of this study used bank industry and manufacturing industry that listed in BEI from 2010 until 2014. Sampling methode of this study used purposive sampling and get 30 companies. The statistics methode used multiple linear regression analysis. The result showed that management ownership, type of industry, profitability, and firm age have no effect to risk management disclosure. This study also showed that all variables has effect to risk management disclosure and the models of the study has goodness of fit.
\end{abstract}

Keyword: the effect of management ownership, type of industry, product diversification, profitability, and firm age to risk management disclosure

\section{PENDAHULUAN}

Ketatnya persaingan usaha menuntut perusahaan besar di Indonesia untuk lebih transparan dalam mengungkap informasi perusahaannya. Informasi akan dianggap informatif jika informasi tersebut relevan dan dapat membentuk kepercayaan baru bagi stakeholders dalam mengambil keputusan. Menurut Jogiyanto (2000:392), informasi yang dipublikasikan adalah suatu pengumuman yang akan memberikan signal bagi investor dalam pengambilan keputusan investasi. Jika pengumuman tersebut mengandung nilai positif, maka diharapkan pasar akan bereaksi pada waktu pengumuman tersebut diterima oleh pasar. Hendriksen (1994:203) mengatakan bahwa pengungkapan dalam pelaporan keuangan merupakan penyajian informasi yang diperlukan untuk operasi optimal pasar modal yang efisien.

Kegagalan perusahaan yang terjadi di Indonesia dalam mengelola risiko valuta asing pada saat krisis moneter tahun 2008 telah mengakibatkan banyaknya perusahaan yang terpaksa harus menjalani proses penyehatan, berganti pemilik, atau bahkan dipailitkan. Terbongkarnya kasus Bank Century pada akhir tahun 2008, membuat dunia perbankan terguncang hingga saat ini. Kasus tersebut terjadi karena adanya kecurangan berupa manipulasi laporan keuangan untuk memunculkan bahwa kinerja mereka tetap baik dan investor tetap menanamkan 
dananya pada perusahaan mereka. PT Allianz pada tahun 2012, melakukan manipulasi kontrak asuransi proyek dan memanipulasi laporan keuangan sehingga investor beranggapan bahwa kinerja perusahaan sangatlah baik (Rahiim, 2013). Hal ini mengindikasikan adanya kelemahan dalam proses manajemen risiko. Kasus lain diberitakan Seputar Indonesia 13 Agustus 2012, mengenai kurang dari 20\% penurunan kapital yang parah dalam sebuah perusahaan diakibatkan risiko keuangan sebagai hasil dari kesalahan manajemen risiko, penurunan permintaan inti produk dan kegagalan mencapai sinergi dari proses akuisisi (Muthohirin,dkk 2012 dalam Sari, 2013).

Fenomena tersebut menimbulkan keraguan para pengguna laporan keuangan terhadap keakuratan dan tranparansi laporan keuangan tahunan perusahaan. Risk management disclosure merupakan salah satu solusi untuk membantu mengembalikan kepercayaan publik dan membantu mengontrol aktivitas manajemen sehingga dapat meminimalisir terjadinya praktik kecurangan pada laporan keuangan, sehingga pengungkapan risiko manajemen harus diungkapkan sesuai dengan kondisi perusahaan yang sebenarnya agar investor dan pemakai informasi lainnya tidak keliru di dalam mengambil keputusan investasi.

Pengungkapan risiko mulai menjadi topik utama sejak tahun 1998 ketika Institute of Chartered Accountants in England and Wales (ICAEW) mempublikasikan sebuah discussion paper berjudul "Financial Reporting of Risk - Proposals for a Statement of Business Risk". ICAEW menyarankan kepada perusahaan untuk menyajikan informasi pengungkapan mengenai risiko bisnisnya dalam laporan tahunan untuk memfasilitasi para stakeholders membuat keputusan (Linsley dan Shrives, 2006 dalam Anisa, 2012).

Penelitian ini mengacu pada penelitian Fathimiyah, dkk (2013) yang meneliti pengaruh struktur kepemilikan terhadap Risk Management Disclosure pada perusahaan perbankan yang listing di BEI tahun 2008-2010. Persamaan penelitian ini dengan penelitian Fathimiyah, dan Zulfikar (2013) adalah pertama adalah menjadikan Risk Management Disclosure sebagai variabel dependen. Kedua adalah menggunakan variabel struktur kepemilikan manajemen sebagai variabel independen. Peneliti memilih variabel kepemilikan manajemen karena dalam hasil penelitian Fathimiyah dan Zulfikar (2013), struktur kepemilikan yang lain tidak memiliki pengaruh terhadap risk management disclosure. Persamaan ketiga adalah menggunakan variabel leverage dan ukuran perusahaan sebagai variabel kontrol, karena dalam penelitian Fathimiyah, dan Zulfikar (2013) Leverage dan ukuran perusahaan dapat menguatkan variabel risk magement disclosure.

Perbedaan penelitian ini dengan penelitian sebelumnya yaitu pertama, dalam penelitian ini dilakukan penambahan empat variabel independen yaitu jenis industri, diversifikasi produk, tingkat profitabilitas, dan umur perusahaan mengikuti saran dari penelitian yang dilakukan oleh Fatimiyah dan Zulfikar (2013). Jenis industri dan diversifikasi produk dari penelitian yang dilakukan oleh Taures (2011). Kedua, objek dalam penelitian ini adalah perusahaan perbankan dan manufaktur yang listing di BEI tahun 2010-2014. Pemilihan objek tersebut digunakan untuk mengetahui besarnya tingkat risk management disclosure di perusahaan-perusahaan tersebut. Pemilihan tahun 2010-2014 memiliki tujuan untuk mengetahui pengungkapan risiko manajemen yang dibuat oleh perusahaan setelah krisis global tahun 2008 . Tahun tersebut dipilih karena tahun yang up to date sehingga hasil dapat tergeneralisasi.

Berdasarkan latar belakang masalah yang telah dijelaskan, maka rumusan masalah dalam penelitian ini adalah: 
1. Apakah Kepemilikan Manajemen berpengaruh tehadap Risk Management Disclosure?

2. Apakah Jenis Industri berpengaruh tehadap Risk Management Disclosure?

3. Apakah Diversifikasi Produk berpengaruh tehadap Risk Management Disclosure?

4. Apakah Tingkat Profitabilitas berpengaruh tehadap Risk Management Disclosure?

5. Apakah Umur Perusahaan berpengaruh tehadap Risk Management Disclosure?

\section{REVIEW LITERATUR DAN HIPOTESIS}

\section{Stakeholder Theory}

Freeman (1984) mendefinisikan stakeholder sebagai "any group or individual who can affect or be affected by the achievement of an organization's objective" bahwa stakeholder merupakan kelompok maupun individu yang dapat mempengaruhi atau dipengaruhi oleh proses pencapaian tujuan suatu organisasi. Teori stakeholder perusahaan tidak hanya beroperasi untuk mencapai tujuannya saja, melainkan perusahaan itu juga harus dapat memberikan manfaat bagi para stakeholder-nya. Stakeholder yang dimaksudkan yaitu para pemegang saham, kreditur, pemerintah, masyarakat, supplier, konsumen dan lainnya yang ikut ambil bagian dalam proses pencapaian tujuan perusahaan (Ghozali dan Chairiri, 2007).

Berdasarkan teori stakeholder, perusahaan yang memiliki tingkat risiko yang tinggi, akan mengungkap lebih banyak informasi risiko untuk menyediakan pembenaran dan penjelasan mengenai apa yang terjadi dalam perusahaan (Amran, et al., 2009 dalam Taures, 2011). Semakin tinggi tingkat risiko perusahaan, semakin banyak pula pengungkapan risiko yang harus dilakukan perusahaan, karena manajemen perlu menjelaskan penyebab risiko, dampak yang ditimbulkan, serta cara perusahaan mengelola risiko (Linsley dan Shrives, 2006 dalam
Ruwita 2012). Semakin banyak informasi yang diungkapkan akan dipahami stakeholder sehingga perusahaan akan dianggap risikonya menjadi berkurang. Hal tersebut akan berdampak pada kepuasan stakeholder, sehingga dapat dikatakan bahwa pengungkapan risiko berpengaruh penting pada kepuasan stakeholder.

\section{Manajemen Risiko}

Menurut Djojosoedarso (1999:4) manajemen risiko adalah pelaksanaan fungsi-fungsi manajemen dalam menanggulangi resiko, terutama resiko yang dihadapi oleh organisasi atau perusahaan, keluarga dan masyarakat. Manajemen risiko adalah proses dan metode yang digunakan oleh perusahaan untuk mengelola risikonya (atau menangkap kesempatan) yang berhubungan dengan pencapaian tujuan-tujuan perusahaan (Amran et al., 2009 dalam Ruwita, 2013).

Risiko menuntut beberapa keputusan manajemen yang memiliki akibat baik atau buruk, karena kebanyakan proyek dan keputusan manajemen mengandung risiko. Risiko juga merupakan suatu peristiwa yang dapat terjadi di masa mendatang sebagai akibat dari tindakantindakan yang telah ditempuh pada masa sekarang. Akibat risiko tersebut menyebabkan mengapa para manajer harus mempertimbangkan pilihan-pilihan yang berbeda terhadap beberapa masalah, dan memperhitungkan kosekuensikosekuensinya dengan cara memfokuskan diri pada risiko-risiko yang lebih nyata (Umar, 2001:7).

Manajemen risiko sangat bermanfaat bagi perusahaan dalam mengelola suatu risiko yang terjadi. Manajemen risiko juga membantu perusahaan untuk mengelola risikonya atau menangkapkesempatanyangberhubungandengan pencapaian tujuan perusahaan agar terhindar dari risiko kerugian yang akan ditimbulkan perusahaan, dan juga untuk mempertahankan dan mengontrol kinerja karyawan. 


\section{Pengungkapan Risiko Manajemen (Risk Management Disclosure)}

Menurut Fathimiyah dan Zulfikar (2013), risk management disclosure dapat diartikan sebagai pengungkapan atas risiko-risiko yang telah dikelola perusahaan atau pengungkapan atas bagaimana perusahaan dalam mengendalikan risiko yang berkaitan di masa mendatang. Perusahaan dikatakan telah mengungkapkan risiko jika pembaca laporan tahunan diberi informasi mengenai kesempatan atau prospek, bahaya, kerugian, ancaman atau eksposur, yang akan berdampak bagi perusahaan sekarang maupun masa mendatang (Linsley dan Shrives, dalam Taures, 2011).

Pengungkapan risiko di Indonesia sudah mulai sering di laporkan, terbukti dari peraturan pemerintah antara lain PSAK No. 60 Tahun 2010 tentang instrumen keuangan tentang pengungkapan dan keputusan ketua BAPEPAM dan LK Nomor: Kep-431/BL/2012 mengenai kewajiban penyampaian laporan tahunan bagi emiten dan perusahaan publik.

\section{Pengaruh Kepemilikan Manajemen Terhadap Risk Management Disclosure}

Menurut Hapsoro (2007), kepemilikan manajemen adalah pihak manajerial dalam suatu perusahaan yang secara aktif berperan dalam mengambil keputusan untuk menjalankan perusahaan. Pihak-pihak tersebut adalah mereka yang duduk di dewan komisaris dan dewan direksi perusahaan. Menurut Dampsey dan Laber dalam Fathimiyah, dkk(2013) kepemilikan manajemen suatu perusahaan yang semakin tinggi menyebabkan semakin besar pula tanggung jawab manajemen dalam mengambil suatu keputusan dan risiko pun menjadi semakin tinggi.

Penelitian yang dilakukan oleh Fathimiyah, dkk (2013) menunjukan bahwa kepemilikan manajemen berpengaruh secara simultan dan memiliki nilai regresi yang positif terhadap risk management disclosure. Penelitian ini sejalan dengan penelitian yang dilakukan oleh Fauziah (2013), dimana dalam penelitian hasil regresinya juga menunjukan hasil yang positif yang artinya ada hubungan positif antara kepemilikan manajemen dengan risk management disclosure.

Manajemen berperan besar dalam menjalankan kelangsungan usaha suatu perusahaan. Manajemen tidak hanya berperan sebagai pengelola perusahaan saja melainkan juga berperan sebagai pemegang saham dan manajemen akan bertanggung jawab atas seluruh kegiatan usaha yang telah dilakukannya dengan melakukan pengungkapan dalam laporan keuangan perusahaan. Berdasarkan hal tersebut maka hipotesis yang dapat dirumuskan adalah:

\section{$\mathbf{H}_{1}$ : Kepemilikan Manajemen berpengaruh positif terhadap Risk Management Disclosure.}

\section{Pengaruh Jenis Industri Terhadap Risk Management Disclosure}

Jenis industri menunjukan keterlibatan perusahaan ke dalam industri-industri tertentu dengan karakteristik kegiatan usaha yang dioperasikan perusahaan (Taures, 2011). Menurut Amran et al. (2009) dalam Taures (2011) perusahaan yang beroperasi pada industri yang berbeda mungkin berpengalaman dalam menghadapi jenis risiko yang berbeda pula. Menurut teori stakeholder, perusahaan bukan entitas yang hanya memenuhi pencapaian tujuannya sendiri, tetapi juga harus memberikan manfaat bagi para stakeholdernya. Oleh karena itu pengungkapan risiko dibutuhkan sebagai bentuk pertanggungjawaban perusahaan terhadap para stakeholder (Anisa dan Prastiwi, 2012).

Penelitian yang dilakukan Taures (2011), jenis industri ditemukan berpengaruh positif terhadap luas pengungkapan risiko didalam penelitian. Namun, berbeda dengan penelitian 
yang dilakukan oleh Anisa dan Prastiwi (2012) yang menunjukan bahwa jenis industri tidak berpengaruh terhadap risk management disclosure, tetapi hasil regresinya menunjukan nilai yang positif yang artinya terdapat hubungan positif antara jenis industri dengan risk management disclosure.

Menurut Hackston dan Milne (1996) dalam Anisa (2012), industri ekstraktif akan mengungkapkan informasi lebih mengenai dampak lingkungan dari kegiatan usahanya daripada industri lain. Perusahaan yang beroperasi dalam industri yang berbeda-beda maka diperkirakanakanmengalamiberbagaijenis risiko. Perusahaan-perusahaan tersebut menghadapi kegiatan usaha, peraturan, kebijakan akuntansi, pengukuran, penilaian dan teknik pengungkapan yang berbeda sesuai dengan karakteristik industrinya, yang akan mengakibatkan pula perbedaan tingkat pengungkapan perusahaannya dan luas pengungkapan risiko manajemen yang akan dilakukan oleh perusahaan. Berdasarkan hal tersebut maka hipotesis yang dapat dirumuskan adalah:

$\mathbf{H}_{2}$ : Jenis Industri berpengaruh positif terhadap
Risk Management Disclosure.

\section{Pengaruh Diversifikasi Produk terhadap Risk Management Disclosure}

Menurut Weston dan Brigham (1990:74), diversifikasi produk merupakan salah satu upaya merencanakan strategi jangka panjang suatu perusahaan. Strategi diversifikasi yang dilakukan perusahaan umumnya mendorong pengungkapan informasi tambahan dalam laporan tahunan, dikarenakan informasi diversifikasi penting untuk memperoleh dukungan dari stakeholder mengenai rencana diversifikasi yang akan dilakukan perusahaan.

Penelitian yang dilakukan oleh Taures (2011) hasil regresi variabel diversifikasi produk menunjukan nilai yang positif, yang artinya bahwa terdapat hubungan positif antara diversifikasi produk dengan risk management disclosure dan juga hasilnya menunjukan bahwa diversifikasi berpengaruh positif terhadap risk management disclosure. Namun, penelitian yang dilakukan Fauziah (2013) tidak ditemukan hubungan positif antara diversifikasi produk dengan risk management disclosure.

Banyak perusahaan menemukan bahwa diversifikasi berkontribusi pada rendahnya outcomes (Amran et al., 2009 dalam Taures, 2011). Selanjutnya, perusahaan yang merencanakan keuntungan melalui diversifikasi yang diharapkan dapat menjelaskan risiko-risiko potensial yang mungkin akan timbul kepada para stakeholder perusahaan. Oleh karena itu, semakin banyaknya diversifikasi produk, maka semakin tinggi pula tingkat pengungkapan yang seharusnya dilakukan, untuk memperoleh dukungan dari stakeholder mengenai rencana diversifikasi yang akan dilakukan perusahaan. Berdasarkan hal tersebut maka hipotesis yang dapat dirumuskan adalah:

$\mathbf{H}_{3}$ : Diversifikasi produk berpengaruh positif terhadap Risk Management Disclosure

\section{Pengaruh Tingkat Profitabilitas terhadap Risk Management Disclosure}

Tingkat profitabilitas menunjukkan keberhasilan atas kemampuan perusahaan dalam menghasilkan laba. Shinghvi dan Desai (1976) dalam Subiyantoro (1996) mengatakan dengan laba yang tinggi perusahaan memiliki cukup dana untuk mengumpulkan, mengelompokkan dan mengolah informasi menjadi lebih bermanfaat serta dapat menyajikan pengungkapan yang lebih komprehensif.

Penelitian yang dilakukan oleh Anisa dan Prastiwi (2012) menunjukan hasil regresi dengan nilai yang positif yang berarti ada hubungan positif antara tingkat profitabilitas dengan risk management disclosure. Penelitian ini sejalan 
dengan yang dilakukan oleh Fauziah (2013) yang hasil regresinya juga menunjukan nilai yang positif yang berarti ada hubungan positif antara tingkat profitabilitas dengan risk management disclosure.

Perusahaan dengan tingkat profitabilitas yang rendah akan mengungkapkan informasi lebih banyak. Hal ini dikarenakan rendahnya profitabilitas mengindikasikan tingginya risiko yang dihadapi perusahaaan (Barry dan Brown, dalam Taures, 2011). Tingkat profitabilitas menunjukkan keberhasilan atas kemampuan perusahaan dalam menghasilkan laba. Menurut Anisa (2012) semakin tinggi tingkat profitabilitas suatu perusahaan maka akan menyebabkan ketertarikan principal untuk membeli saham perusahaan tersebut. Semakin tinggi institutional investor maka akan semakin kuat kontrol eksternal perusahaan. Berdasarkan hal tersebut maka hipotesis yang dapat dirumuskan adalah:

$\mathbf{H}_{4}$ : Tingkat profitabilitas berpengaruh positif terhadap Risk Management Disclosure.

\section{Pengaruh Umur Perusahaan terhadap Risk Management Disclosure}

Umur perusahaan menunjukkan perusahaan tetap eksis (survive), mampu bersaing, dan memanfaatkan peluang bisnis dalam suatu perekonomian. Perusahaan cenderung untuk memberikan pengungkapan sukarela ketika mereka berencana untuk menerbitkan utang publik atau ekuitas atau mengakuisisi perusahaan lain dalam rangka memberikan informasi eksplisit investor dan mempengaruhi persepsi mereka (Healy dan Palepu, dalam Widodo, 2014).

Marwata (2001) dalam Wardani mengatakan bahwa umur perusahaan diperkirakan memiliki hubungan positif dengan kualitas pengungkapan. Perusahaan yang berumur lebih tua memiliki pengalaman yang lebih banyak dalam mempublikasi laporan keuangan. Perusahaan yang memiliki pengalaman yang lebih banyak akan lebih mengetahui kebutuhan investor akan informasi tentang perusahaannya.

Perusahaan yang terdaftar di pasar modal lebih lama memiliki banyak pengalaman untuk pengungkapan informasi dengan mempertimbangkan reaksi pasar terhadap pengungkapan yang sesuai. Suatu perusahaan sudah terdaftar di bursa efek Indonesia dan go publik, maka perusahaan harus mempublikasikan pelaporan keuangan mereka kepada masyarakat dan pemakai laporan keuangan agar informasi yang terkandung di dalamnya dapat segera digunakan oleh pihak-pihak yang membutuhkan tersebut. Berdasarkan hal tersebut maka hipotesis yang dapat dirumuskan adalah:

$\mathbf{H}_{5}$ : Umur Perusahaan berpengaruh positif terhadap Risk Management Disclosure.

\section{Kerangka Pemikiran}

Variabel

\section{Independen}

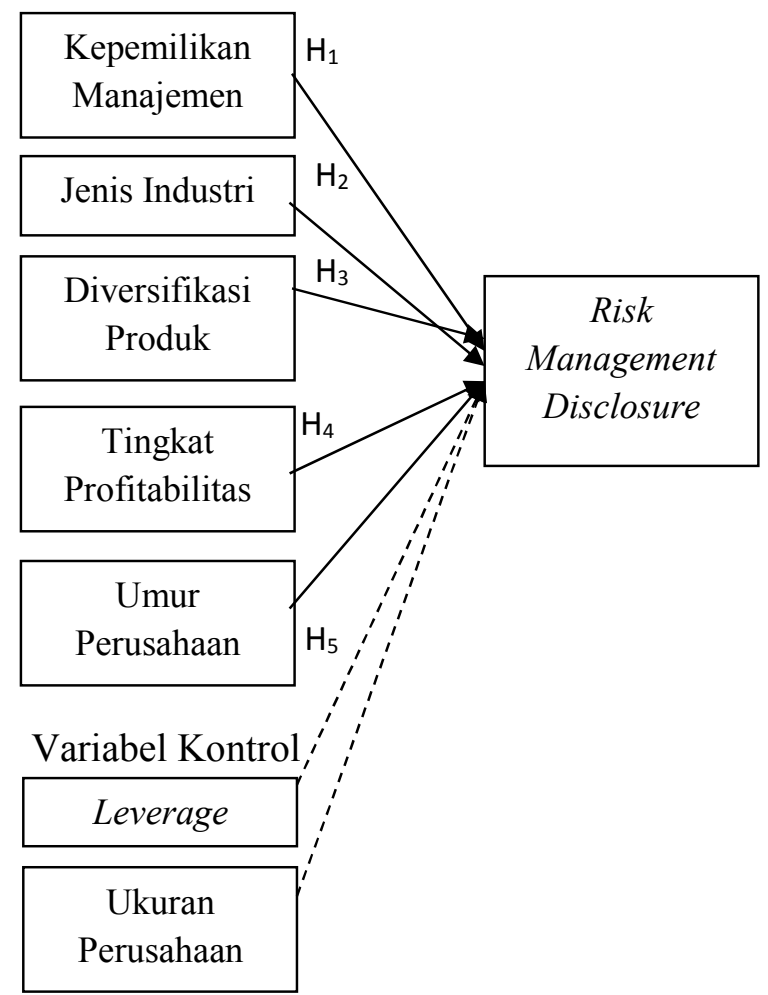

\section{Gambar 1}

Model Penelitian 


\section{METODE PENELITIAN}

\section{Populasi dan Sampel}

Populasi dalam penelitian ini adalah perusahaan perbankan dan perusahaan manufaktur yang listing di BEI pada tahun 20102014. Pengambilan sampel dilakukan dengan menggunakan metode purposive sampling yaitu sampel dipilih berdasarkan ketersediaan informasi dan kesesuaian dengan kriteria yang telah di tentukan dalam penelitian ini. Metode ini memilih sample berdasarkan ketersediaan informasi dan kesesuaian dengan kriteria yang telah ditentukan dalam penelitian.

Berdasarkan pengambilan sampel dengan menggunakan metode purposive sampling diperoleh sampel sebanyak 15 perusahaan perbankan dan 15 perusahaan manufaktur, sehingga jumlah sampel secara keseluruhan selama 5 tahun sebanyak 150 data observasi.

\section{Jenis Penelitian}

Penelitian ini diajukan untuk mengetahui pengaruh kepemilikan manajemen, diversifikasi produk, jenis industri, tingkat profitabilitas dan umur perusahaan terhadap risk management disclosure. Jenis data yang digunakan dalam penelitian ini adalah data sekunder, yaitu data yang berasal dari pihak ketiga atau pihak lain yang dijadikan sampel dalam suatu penelitian. Data tersebut berupa annual report yang listing di Bursa Efek Indonesia (BEI). Sumber data dalam penelitian ini diperoleh melalui situs yang dimiliki oleh BEI. Studi pustaka atau literatur melalui buku teks, dan jurnal ilmiah serta sumber tertulis lainnya yang berkaitan dengan informasi yang dibutuhkan, juga dijadikan sebagai sumber pengumpulan data.

\section{Operasional dan Pengukuran Variabel}

\section{Management Disclosure}

Pengukuran variabel dependen ini dengan menggunakan jumlah pengungkapan risiko yang disajikan dalam laporan tahunan perusahaan sesuai dengan penelitian yang dilakukan oleh Anisa dan Prastiwi (2012). Menghitung index wallace menurut Soewardjono (2005) yaitu:

Disclosure Index: $\frac{\mathrm{n}}{\mathrm{k}}$ x 100\%

Keterangan:

$\mathrm{n}$ : pengungkapan yang dilaksanakan perusahaan

$\mathrm{k}$ : jumlah item yang dianjurkan untuk diungkapkan

\section{Kepemilikan Manajemen}

Menurut Mathiesen (2004), kepemilikan manajemen adalah persentase suara yang berkaitan dengan saham dan option yang dimiliki oleh manajer dan direksi suatu perusahaan. Kepemilikan saham oleh manajemen perusahaan yang diukur dengan prosentase jumlah saham yang dimiliki oleh manajemen ( Demsetz dan Lehn, dalam Fatimiyah dan Zulfikar, 2013). Menurut Demsetz dan Lehn dalam Fatimiyah dan Zulfikar (2013) untuk mengukur rasio kepemilikan manajemen adalah sebagai berikut:

$$
\begin{gathered}
\text { Kepemilikan } \\
\text { Manajemen }
\end{gathered}=\frac{\text { Esahammanajer }}{\text { Totalsahammanajer }}
$$

\section{Jenis Industri}

Pengukuran ini berdasarkan pada penelitian Taures (2011), perusahaan yang masuk kedalam industri manufaktur diberikan nilai 1 (satu), sedangkan perusahaan yang masuk kedalam industri perbankan diberikan nilai 0 (nol).

\section{Diversifikasi produk}

Diversifikasi merupakan salah satu dari ukuran-ukuran utama yang dilakukan perusahaan untuk memperbandingkan risiko (Amran et al., dalam Taures, 2011). Menurut penelitian Taures (2011) diversifikasi produk diukur menggunakan variabel dummy. Perusahaan yang melakukan diversifikasi produk diberi nilai 1, dan perusahaan 
yang tidak melakukan diversifikasi produk diberi nilai 0 .

\section{Tingkat profitabilitas}

Rumus yang digunakan untuk menghitung net profit margin adalah jumlah laba bersih (penjualan neto-harga pokok penjualan) terhadap jumlah penjualan bersih. Net Profit Margin Ratio (NPMR) dirumuskan sebagai berikut (Halim dan sarwoko, 1993:62):

$$
\begin{gathered}
\text { Net Profit } \\
\text { Ratio }
\end{gathered}=\frac{E A T}{\text { PenjualanDersih }}
$$

Keterangan:

EAT: laba bersih (laba setelah biaya bunga dan pajak)

\section{Umur Perusahaan}

Umur perusahaan diukur dari tanggal pendiriannya maupun dari tanggal terdaftarnya di BEI (Owusa dan Ansah, dalam Bestivao, 2013).

\section{Leverage}

Apabila perusahaan memiliki tingkat risiko utang yang lebih tinggi dalam struktur modal, kreditur dapat memaksa perusahaan untuk mengungkapkan informasi lebih lanjut. Rumus dept to asset ratio sebagai berikut (Horne dan Wachowach, 2009):

$$
\text { Debt to Asset Ratio }=\frac{\text { TotalUtang }}{\text { TotalAset }}
$$

\section{Ukuran Perusahaan}

Ukuran perusahaan menunjukan jumlah asset yang dimiliki oleh perusahaan (Jogiyanto, 2007). Selain itu, total asset merupakan ukuran yang relative stabil dibanding dengan ukuran lain dalam mengukur ukuran perusahaan (Sudarmaji, 2007).

Ukuran Perusahaan $=$ Ln Total Aset

\section{Metode Analisis Data}

Sebelum dianalisis dan di uji hipotesisnya, terlebih dahulu dilakukan uji asumsi klasik yaitu uji normalitas, uji multikolinearitas, uji autokorelasi, dan uji heterokedastisitas. Setelah itu barulah melakukan analisis dan pengujian hipotesis dengan menggunakan Regresi Linier Berganda, Uji F dan Uji t. Model persamaan Regresi Linier berganda:

$\mathrm{RMD}=\alpha+\beta_{1} \mathrm{KM}+\beta_{2} \mathrm{JI}+\beta_{3} \mathrm{DPROD}+\beta_{4} \mathrm{NPM}$ $+\beta_{5} \mathrm{AGE}+\beta_{6} \mathrm{LEV}+\beta_{7} \mathrm{TA}+e$

Keterangan:

$\begin{array}{ll}\text { RMD } & \text { : Risk Management Disclosure } \\ \text { JI } & \text { : Jenis Industri } \\ \text { DPROD } & \text { : Diversifikasi Produk } \\ \text { NPM } & \text { : Tingkat Profitabilitas } \\ \text { AGE } & \text { : Umur Perusahaan } \\ \text { LEV } & : \text { Leverage } \\ \text { TA } & : \text { Ukuran Perusahaan } \\ \alpha & : \text { Konstanta } \\ \beta 1, \beta 2, \beta 3, & \\ \beta 4, \beta 5 & : \text { Koefisien } \\ e & : \text { Standar error }\end{array}$

HASIL PENELITIAN DAN PEMBAHASAN

Berdasarkan Tabel 1 menunjukkan fungsi deskriptif setiap variabel yang digunakan dalam penelitian. Nilai minimum menunjukkan besaran terendah dari setiap variabel, sedangkan nilai maksimum merupakan nilai tertinggi yang dicapai variabel.

Tabel 1

Statistik Deskriptif

\begin{tabular}{|l|l|r|r|r|r|}
\hline Variabel & N & \multicolumn{1}{l|}{ Min } & Max & Mean & Std. Dev \\
\hline RMD & 150 & .17 & .96 & .4958 & .19211 \\
KM & 150 & .00 & .92 & .1232 & .17543 \\
JI & 150 & .00 & 1.00 & .5000 & .50168 \\
DIPROD & 150 & .00 & 1.00 & .9667 & .18011 \\
NPM & 150 & .00 & .97 & .4151 & .31868 \\
AGE & 150 & 5.00 & 32.00 & 18.2667 & 6.64504 \\
LEV & 150 & .03 & .94 & .6041 & .29030 \\
TA & 150 & 11.27 & 20.57 & 16.2721 & 2.60644 \\
\hline
\end{tabular}

Sumber: data sekunder yang dioleh 2015 
Uji Asumsi Klasik

\begin{tabular}{|l|l|r|}
\multicolumn{3}{c}{ Uji Normalitas } \\
Tabel 2 \\
Uji Normalitas \\
\begin{tabular}{|l|l|r|}
\hline \multicolumn{1}{|c|}{} & $\begin{array}{c}\text { Unstandarized } \\
\text { Residual }\end{array}$ \\
\hline N & & 150 \\
Normal Parameter & Mean & .0000000 \\
& Std. Deviation & .15363681 \\
Most Extreme & Absolute & .088 \\
Differences & Positive & .088 \\
& Negative & -.047 \\
Kolmogorov- & & 1.075 \\
Smirnov Z & & .198 \\
Asymp. Sig. & & \\
(2-tailed) & & \\
\hline
\end{tabular}
\end{tabular}

Sumber: data sekunder yang diolah 2015

Berdasarkan Tabel 2 dapat diketahui bahwa nilai Asymp.Sig.(2-tailed) sebesar 0,198. Hasil tersebut menunjukkan bahwa $p$ value $0,198>0,05$. Jadi dapat disimpulkan bahwa data residual model regresi penelitian ini terdistribusi normal.

\section{Uji Multikolinearitas}

Tabel 3

Uji Multikolinearitas

\begin{tabular}{|l|c|c|}
\hline \multicolumn{1}{|c|}{ Variabel } & Tolerance & VIF \\
\hline KM & .879 & 1.138 \\
JI & .121 & 8.256 \\
DIPROD & .828 & 1.208 \\
NPM & .193 & 5.177 \\
AGE & .768 & 1.302 \\
LEV & .209 & 4.783 \\
TA & .298 & 3.359 \\
\hline
\end{tabular}

Sumber: data sekunder yang dioleh 2015

Berdasarkan hasil uji multikolonieritas pada Tabel 3 dapat diketahui bahwa variabel kepemilikan manajemen (KM), jenis industri
(JI), diversifikasi produk (DIPROD), tingkat profitabilitas (NPM), umur perusahaan (AGE), leverage (LEV), dan ukuran perusahaan (TA) tidak ada yang memiliki nilai tolerance $<$ 0,10 dan memiliki nilai VIF $>10$. Jadi dapat disimpulkan bahwa dalam model regresi tidak terjadi multikolinearitas.

\section{Uji Autokorelasi \\ Tabel 4 \\ Uji Autokorelasi}

\begin{tabular}{|r|c|r|r|r|}
\hline R & R Square & DW & D1 & Du \\
\hline .600 & .360 & 2.153 & 1.637 & 1.832 \\
\hline
\end{tabular}

Sumber: data sekunder yang dioleh 2015

Hasil perbandingan menunjukkan nilai DW 2.138 lebih besar dari batas atas (du) 1.832 dan kurang dari $4-1.832(\mathrm{du}<\mathrm{d}<4-\mathrm{du})$, maka dapat disimpulkan bahwa tidak bisa menolak $\mathrm{H} 0$ yang menyatakan bahwa tidak ada autokorelasi positif atau negative dan disimpulkan tidak terdapat autokorelasi.

\section{Uji Heterokedasitas}

Berdasarkan gambar 2, terlihat titik-titik tersebar tanpa membentuk suatu pola yang jelas dan tersebar secara acak baik di atas maupun di bawah angka 0 (nol) pada sumbu Y. Hal ini berarti tidak terjadi heteroskedastisitas pada model regresi linier berganda.

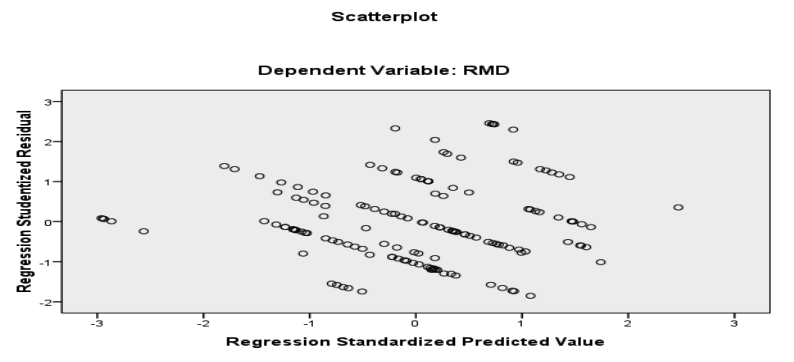

Gambar 2 
Uji Heterokedastisitas

Uji Hipotesis

Uji $\mathbf{R}^{2}$ (Koefisien Determinasi)

Tabel 5

$\mathbf{U j i} \mathbf{R}^{2}$

\begin{tabular}{cccc}
\hline $\mathrm{R}$ & $\mathrm{R}$ Square & $\begin{array}{c}\text { Adjusted } \\
\text { Square }\end{array}$ & $\begin{array}{c}\text { Std. Error of } \\
\text { the Estimate }\end{array}$ \\
\hline .600 & .360 & .329 & .15738 \\
\hline
\end{tabular}

Sumber: data sekunder yang diolah 2015

Berdasarkan hasil koefisien determinasi pada tabel 4.8 dapat diketahui bahwa koefisien deterimasi penelitian ini memiliki nilai Adjusted R Square sebesar 0.329. Hasil tersebut menunjukkan bahwa kemampuan variabel struktur kepemilikan manajemen, jenis industri, diversifikasi produk, tingkat profitabilitas dan umur perusahaan dalam menjelaskan perubahan risk management disclosure sebesar 32,9\%, sisanya sebesar $67,1 \%$ dijelaskan oleh variabel lain di luar model penelitian ini.

\section{Uji F}

\section{Tabel 6}

Uji F

\begin{tabular}{|c|c|c|c|c|}
\hline $\begin{array}{c}\text { Sum of } \\
\text { Square }\end{array}$ & Df & $\begin{array}{c}\text { Mean } \\
\text { Square }\end{array}$ & F & Sig. \\
\hline 7.887 & 7 & .238 & 11.432 & 000 \\
\hline 5.956 & 142 & .025 & & \\
\hline 13.843 & 149 & & & \\
\hline
\end{tabular}

Sumber: data sekunder yang diolah 2015

Berdasarkan Tabel 4.9 dapat diketahui bahwa model regresi penelitian ini memiliki nilai F hitung sebesar 11.154 sedangkan besarnya nilai $\mathrm{F}$ tabel didasarkan pada $\mathrm{df}_{1}=7 \mathrm{dan}_{\mathrm{df}_{2}}=142$ diperoleh nilai $F$ tabel sebesar 2,07. Hasil tersebut menunjukkan bahwa $\mathrm{F}$ hitung $11.432>\mathrm{F}$ tabel 2,07, maka model regresi layak digunakan.
Uji t

Tabel 7

Uji Hipotesis

\begin{tabular}{|l|r|c|}
\hline \multicolumn{1}{|c|}{ variabel } & \multicolumn{1}{c|}{$\mathrm{t}$ hitung } & $\mathrm{t}$ table \\
\hline KM & -.447 & 1,655655 \\
$\mathrm{JI}$ & .948 & 1,655655 \\
DIPROD & 2.527 & 1,655655 \\
NPM & -1.674 & 1,655655 \\
AGE & -.696 & 1,655655 \\
\hline
\end{tabular}

Sumber: data sekunder yang diolah 2015

Pengaruh Kepemilikan Manajemen Terhadap Risk Management Disclosure

Diketahui bahwa nilai $\mathrm{t}$ hitung lebih kecil dari t tabel $(-0,447<1,6557)$. Hasil ini menunjukkan bahwa nilai t hitung berada pada daerah $\mathrm{H}_{0}$ diterima, sehingga dapat disimpulkan hipotesis satu $\left(\mathrm{H}_{1}\right)$ tidak diterima.

Pengaruh Jenis Industri Terhadap Risk Management Disclosure

Diketahui bahwa nilai $\mathrm{t}$ hitung lebih kecil dari $\mathrm{t}$ tabel $(0,948<1,6557)$. Hasil ini menunjukkan bahwa nilai t hitung berada pada daerah $\mathrm{H}_{0}$ diterima, sehingga dapat disimpulkan hipotesis dua $\left(\mathrm{H}_{2}\right)$ tidak diterima.

Pengaruh Diversifikasi Produk Terhadap Risk Management Disclosure

Diketahui bahwa nilai $\mathrm{t}$ hitung lebih kecil dari $t$ tabel $(2,527<1,6557)$. Hasil ini menunjukkan bahwa nilai t hitung berada pada daerah $\mathrm{H}_{0}$ ditolak, sehingga dapat disimpulkan hipotesis tiga $\left(\mathrm{H}_{3}\right)$ diterima.

Pengaruh Tingkat Profitabilitas Terhadap Risk Management Disclosure

Diketahui bahwa nilai $\mathrm{t}$ hitung lebih kecil dari t tabel $(-1,674<1,6557)$. Hasil ini menunjukkan bahwa nilai t hitung berada pada daerah $\mathrm{H}_{0}$ diterima, sehingga dapat disimpulkan hipotesis empat $\left(\mathrm{H}_{4}\right)$ tidak diterima. 
Pengaruh Umur Perusahaan Terhadap Risk Management Disclosure

Diketahui bahwa nilai $\mathrm{t}$ hitung lebih kecil dari $t$ tabel $(-0,696<1,6557)$. Hasil ini menunjukkan bahwa nilai t hitung berada pada daerah $\mathrm{H}_{0}$ diterima, sehingga dapat disimpulkan hipotesis lima $\left(\mathrm{H}_{5}\right)$ tidak diterima.

\section{Pembahasan}

Pengaruh Kepemilikan Manajemen terhadap Risk Management Disclosure

Hasil penelitian ini menunjukkan bahwa variabel kepemilikan manajemen tidak memiliki pengaruh positif terhadap risk management disclosure. Kepemilikan saham oleh manajemen tidak dapat mendorong banyaknya pengungkapan risiko-risiko yang telah dikelola perusahaan.

Hasil penelitian ini konsisten dengan penelitian Venny Fathimiyah, dkk (2013) yang menguji struktur kepemilikan manajemen terhadap risk management disclosure. Penelitian Venny Fathimiyah, dkk (2013) menunjukkan bahwa kepemilikan manajemen tidak berpengaruh dan tidak signifikan terhadap risk management disclosure.

Pengaruh Kepemilikan Manajemen terhadap Risk Management Disclosure

Berdasarkan hasil penelitian ini menerima hipotesis dua $\left(\mathrm{H}_{2}\right)$ yang menyatakan bahwa jenis industri tidak berpengaruh positif terhadap risk management disclosure. Artinya, perusahaan manufaktur persaingan yang lebih ketat dibandingkan perbankan, dan pengungkapan risiko yang lebih luas menguntungkan para pesaing dalam melihat sisi kelemahan perusahaan pengungkapan manajemen risiko yang dilakukan perusahaan akan tinggi pula.

Hasil penelitian konsisten dengan penelitian yang dilakukan Anisa dan Prastiwi (2012) yang menunjukkan bahwa jenis industri tidak berpengaruh positif terhadap risk management disclosure. Sedangkan, penelitian Taures (2011) menunjukkan bahwa jenis industri berpengaruh positif terhadap risk management disclosure.

Pengaruh Diversifikasi Produk terhadap Risk Management Disclosure

Berdasarkan hasil penelitian ini menerima hipotesis tiga $\left(\mathrm{H}_{3}\right)$ yang menyatakan bahwa diversifikasi produk berpengaruh positif terhadap risk management disclosure. Hubungan positif ini berarti semakin tinggi diversifikasi produk yang dilakukan perusahaan maka pengungkapan manajemen risiko yang dilakukan perusahaan akan tinggi pula.

Hasil penelitian inikonsisten dengan penelitian Taures (2011) yang menguji diversifikasi produk terhadap risk management disclosure. Penelitian Taures (2011) menunjukkan bahwa diversifikasi produk berpengaruh positif terhadap risk management disclosure. Sedangkan, penelitian Fauziah (2013) menunjukan bahwa diversifikasi produk tidak berpengaruh positif terhadap risk management disclosure.

Pengaruh Tingkat Profitabilitas terhadap Risk Management Disclosure

Berdasarkan hasil penelitian tidak menerima hipotesis empat $\left(\mathrm{H}_{4}\right)$ yang menyatakan bahwa tingkat profitabilitas tidak berpengaruh positif terhadap risk management disclosure. Hal ini disebabkan karena sedikitnya tingkat profitabilitas yang dimiliki oleh sampel penelitian. Berdasarkan hasil pengujian statistik diskriptif yang menunjukkan bahwa nilai rata-rata (mean) proporsi tingkat profitabilitas dalam penelitian ini kecil atau rendah.

Hasil penelitian ini konsisten dengan hasil penelitian Taures (2011) dan Anisa dan Prastiwi (2012), yang menunjukkan bahwa tingkat profitabilitas tidak berpengaruh berpengaruh positif terhadap risk management disclosure. 
Pengaruh Umur Perusahaan terhadap Risk Management Disclosure

Berdasarkan hasil penelitian tidak menerima hipotesis lima $\left(\mathrm{H}_{5}\right)$ yang menyatakan bahwa umur perusahaan tidak berpengaruh positif terhadap risk management disclosure. Semakin lama perusahaan menjadi perusahaan publik mungkin lebih mengerti dan mengetahui kebutuhan informasi yang dibutuhkan oleh para stakeholder, sehingga perusahaan hanya memberikan pengaruh yang positif terhadap perusahaan (Amalia, Dessy 2005).

Hal tersebut menjelaskan bahwa semakin lama perusahaan mempublikasikan laporan tahunan, maka perusahaan lebih mengetahui kebutuhan kebutuhan informasi untuk para penggunannya atau semakin mengetahui kebutuhan informasi untuk para stakeholder perusahaan melalui pengungkapan risiko manajemen yang dilaporkan dalam laporan tahunan perusahaan sebagai alat untuk pengawasan kinerja perusahaan agar kelangsungan usaha perusahaan tetap terjaga.

\section{KESIMPULAN DAN SARAN}

\section{Kesimpulan}

Hasil uji koefisien determinasi (Adjusted $R$ Square) menunjukkan nilai 32,9\%. Hasil tersebut menunjukkan bahwa kemampuan variabel kepemilikan manajemen, jenis industri, diversifikasi produk, tingkat profitabilitas dan umur perusahaan dalam menjelaskan perubahan risk management disclosure sebesar 32,9\%, sisanya sebesar $67,1 \%$ dijelaskan oleh variabel lain di luar model penelitian ini.

Berdasarkan hasil uji $\mathrm{F}$ diperoleh $\mathrm{F}$ hitung $>\mathrm{F}$ tabel, artinya semua variabel independen dalam penelitian yang terdiri dari kepemilikan manajemen, jenis industri, diversifikasi produk, tingkat profitabilitas dan umur perusahaan berpengaruh terhadap risk management disclosure dan model dalam penelitian ini bagus dan layak atau model yang digunakan dalam penelitian tepat ( $f i t$ ).

Berdasarkan hasil uji t, dapat disimpulkan bahwa $\mathrm{H}_{3}$ diterima, dimana jenis industri, diversifikasi produk mempunyai pengaruh positif terhadap risk management disclosure. $\mathrm{H}_{1}$, $\mathrm{H}_{2}, \mathrm{H}_{4}, \mathrm{H}_{5}$ tidak diterima, dimana kepemilikan manajemen, jenis industry, tingkat profitabilitas dan umur perusahaan tidak berpengaruh positif terhadap risk management disclosure.

\section{Saran}

Penelitian selanjutnya sebaiknya menambah jumlah sampel pada jenis perusahaan lain, seperti perusahaan jasa asuransi, menambahkan periode tahun penelitian agar hasilnya lebih akurat, serta menambah variabel lain yang juga mempunyai pengaruh terhadap risk management disclosure, seperti ukuran dewan komisaris.

\section{DAFTAR PUSTAKA}

Almilia, Luciana S. dan Ikka Retrinasari. 2007. "Analisis Pengaruh Karakteristik Perusahaan terhadap Kelengkapan Pengungkapan dalam Laporan Tahunan Perusahaan Manufaktur yang Terdaftar di BEJ". Proceeding Seminar Nasional Inovasi dalam Menghadapi Perubahan Lingkungan Bisnis FE Universitas Trisakti. Jakarta, 9 Juni, 2007

Ali, Mahsyhud. 2006. Manajemen Risiko Strategi Perbankan dan Dunia Usaha Menghadapi Tantangan Globalisasi Bisnis. Jakarta: Raja Grafindo Persada

Amalia, Dessy (2005), Faktor-faktor yang Mempengaruhi Luas Pengungkapan Sukarela (Voluntary Disclosure) pada Laporan Tahunan Perusahaan yang Tercatat di Bursa Efek Jakarta, Jurnal Akuntansi Pemerintah, Vol. 1, No. 2.

Amanza,Arya. 2011. "Analisis Faktor-Faktor Yang Mempengaruhi Praktik Perataan 
Laba (income Smoothing)".(Studi Empiris pada Perusahaan Manufaktur yang Terdaftar di BEI Tahun 20062011).Skripsi.UNDIP

Anisa, Windi Gessy dan Andri Prastiwi, 2012. Analisis Faktor yang Mempengaruhi Pengungkapan Manajemen Risiko : Studi Empiris pada Laporan Tahunan Perusahaan-Perusahaan Non-Keuangan yang Terdaftar si BEI Tahun 2010. Skripsi. Semarang: Fakultas Ekonomika dan Bisnis Universitas Diponegoro

Anthony, Robert, N, dan Vijay Govindarajan, 2005. Sistem Pengendalian Manajemen (Terjemahan). Jakarta : Salemba Empat

Belkaoui dan Ahmed Riahi. 2000. Teori Akuntansi Buku 1. Jakarta: Salemba Empat.

Bestivano, Wildham. 2013. Pengaruh Ukuran Perusahaan, Umur Perusahaan, Profitabilitas dan Leverage terhadap Perataan Laba : Studi Empiris Pada Perusahaan yang Terdaftar di Bursa Efek Indonesia. Skripsi. Padang: Fakultas Ekonomi Universitas Negeri Padang

Binsar H. Simanjuntak dan Lusy Widiastuti. 2004. Faktor-faktor yang Mempengaruhi Kelengkapan Pengungkapan Laporan Keuangan pada Perusahaan Manufaktur yang Terdaftar di Bursa Efek Jakarta. Jurnal Riset Akuntansi Indonesia Vol 7 No 3. September

Djojosoedarso, Soeisno. 1999. Prinsip-Prinsip Manajemen Risiko dan Asuransi. Jakarta : Salemba Empat

Doi, Cristian. 2014. Analisis Pengaruh Karakteristik Perusahaan Terhadap Pengungkapan Risiko (Studi Empiris Pada Perusahan Non-Finansial Yang Listing Di Bursa Efek Indonesia Tahun 2010-2012). Skripsi. Semarang: Universitas Diponegoro

Fathimiyah, Veny, dkk. 2013. Pengaruh Struktur Kepemilikan Terhadap Risk
Management Disclosure : Study Survei Industri Perbankan yang Listing di Bursa Efek Indonesia Tahun 2008-2010. Simposium Nasional Akuntansi XV. Banjarmasin

Fauziah, Wina, 2013. Pengaruh Kepeilikan Manajemen, Diversifikasi Produk, Jenis Industri dan Tingkat Profitabilitas Terhadap Risk management Disclosure. (Studi Empiris pada Perusahaan Manufaktur dan Perusahaan Perbankan yang Listing di BEI Tahun 2008-2012). Skripsi Tidak Dipublikasikan. Magelang : Fakultas Ekonomi Akuntansi. UMM

Febrina, Kandida. 2013. Analisis Faktor Faktor yang Mempengaruhi Pengungkapan Enterprise Risk Management pada Perusahaan Sektor Keuangan yang Terdaftar di Bursa Efek Indonesia. Repository.upi.edu: Universitas Pendidikan Indonesia

Freeman, R. E. (1984). Strategic Management: A Stakeholder Approach. Boston: Pitman Publishing

Ghozali, Imam. 2013. Aplikasi Analisis Multivariat dengan Program IMB SPSS 19. Semarang: Badan Penerbit Universitas Diponegoro.

Ghozali, Imam dan Anis Chairiri. 2007. Teori Akuntansi. Semarang: Badan Penerbitan Universitas Diponogoro

Halim, Abdul dan Sarwoko. 1993. Manajemen Keuangan (Dasar-Dasar Pembelajaran Perusahaan), Buku 1 Edisi 2. Yogyakarta: BPFE

Hapsoro, Dody. 2007. Pengaruh Struktur Kepemilikan Terhadap Transparansi : Studi Empiris Di Pasar Modal. Vol. 18 No. 2, hal 65-85.

Haryanto. Samuel. 2005. Faktor-Faktor yang Mempengaruhi Luas Pengungkapan Sukarela Dalam Laporan Tahunan Perusahaan Manufaktur di Bursa Efek 
Jakarta. skripsi. Semarang: Universitas Katolik Soegijapranata

Hendriksen, and Eldon, S., 1994, Teori Akuntansi Manajemen, Edisi ketiga, alih bahasa Indonesia Gunawan $\mathrm{H}$; Jakarta: Erlangga.

Horne, James C Van dan John M Wachowicz JR. 2009. Prinsip-Prinsip Manajemen Keuangan Edisi Tigabelas Buku 1. Jakarta: Salemba Empat

Jogiyanto. 2000. Teori Portofolio dan Analisis Sekuritas. Edisi Ketiga. Yogyakarta : BPFE Yogyakarta.

Jogiyanto, 2007. Teori Portofolio dan Analisis Investasi. Edisi Pertama. Yogyakarta: BPFE

Kasmir. Bank dan Lembaga Keuangan Lainnya. Edisi Revisi 2008. Jakarta: PT. RAJAGRAFINDO PERSADA.

Kusumaningrum, Amilia. 2013. Pengaruh Kepemilikan Institusional Dan Karakteristik Dewan Komisaris Terhadap Pengungkapan Manajemen Risiko: Studi Empiris pada Laporan Tahunan Perusahaan-Perusahaan NonKeuangan yang terdaftar di BEI tahun 2012. Skripsi. Semarang : Fakultas Ekonomika dan Bisnis. UNDIP

Mathiesen, Terry. 2004. Akuntansi IntermmediateEdisi Sepuluh. Jakarta : Erlangga

Meizaroh dan Jurica Lucyanda. 2011. "Pengaruh Corporate Governance dan Konsentrasi Kepemilikan pada Pengungkapan Enterprise Risk Management". Simposium Nasional Akuntansi XIV. Banda Aceh

Niswonger R.C., Warren C.S., Reeve J.M., dan Fess P.E. 2000. Prinsip-Prinsip Akuntansi 2. Jakarta : Erlangga

Peraturan Pemerintah PSAK 60 Tahun 2010 tetang Instrumen Keuangan tentang
Pengungkapan dan Keputusan Ketua BAPEPAM

Peraturan Pemerintah Laporan Keuangan Nomor : Kep-431/BL/2012 tetang Kewajiban Penyampaian Laporan Tahunan Bagi Emiten dan Perusahaan Publik

Pramono, Ferry Andriawan. (2011). "Analisis Pengaruh Karakteristik Perusahaan Terhadap Kualitas Pengungkapan Corporate Governance Pada Laporan Tahunan (Studi Empiris Pada Perusahaan Yang Terdaftar Dalam LQ45)”. Skripsi. Universitas Diponegoro.

Prayoga, Edo dan Luciana. 2013. Pengaruh Struktur Kepemilikan dan Ukuran Perusahaan terhadap Pengungkapan Manajemen Resiko. Jurnal Akuntansi dan Keuangan. Vol 4 No 1. STIE Perbanas Surakarta

Putri, Enesti. 2013. Pengaruh Komisaris Independen, Komite Manajemen Risiko,ReputasiAuditorDanKonsentrasi Kepemilikan Terhadap Pengungkapan Enterprise Risk Management. Dimensi Coso Erm Framework. (Studi Empiris Pada Perusahaan Nonfinancial Yang Terdaftar Di Bursa Efek Indonesia Periode Tahun 2009-2011 ). Skripsi. Jakarta: Universitas Islam Negeri Syarif Hidayatullah

Rahiim, Defriandio. 2013. "Pengaruh Mekanisme Corporate Governance Dan Kualitas Kantor Akuntan Publik Terhadap Integritasn Laporan Keuangan (Studi Empiris Pada Perusahaan Manufaktur Yang Terdaftar Di Bursa Efek Indonesia Pada Tahun 2009-2011)". Skripsi. Jakarta : Universitas Negeri Islam Syarif Hidayatullah

Retno, Reny Dyah dan Denies Priantinah. 2012. "Pengaruh Good Corporate Governance dan Pengungkapan Corporate Social Responsibility terhadap Nilai Perusahaan 
(Studi Empiris pada Perusahaan yang Terdaftar di BEI Periode 2007-2010)". Jurnal Nominal Vol. 1 No. 2 Tahun 2012 Riyanto, Bambang. 1999. Dasar-Dasar Pembelajaran Perusahaan. Yogyakarta: PT BPFE

Rustiarini, Ni Wayan. 2011. Pengaruh Struktur Kepemilikan Saham pada Pengungkapan CSR. Skripsi. Denpasar: Universitas Mahasaraswati Denpasar

Ruwita, Cahya. 2012. Analisis Pengaruh KarakteristikPerusahaan dan Corporate Governance Terhadap Pengungkapan Risiko Perusahaan (Studi Empiris Pada Perusahaan-Perusahaan manufaktur yang terdaftar di Bursa Efek Indonesia). Skripsi. Semarang:Fakultas Ekonomika dan Bisnis Universitas Diponegoro

Saidah, Siti. 2014. Pengaruh Mekanisme Corporate Governance Terhadap Pengungkapan Risiko Perusahaan : Studi Empiris pada Laporan Tahunan Perusahaan Non Keuangan Yang Terdaftar di BEI Periode 2011-2013. Surabaya. Fakultas Ekonomi Universitas Negeri Surabaya

Saputro, Cadra. 2014. Pengaruh Struktur Kepemilikan, Leverage Dan Ukuran Perusahaan Terhadap Pengungkapan Manajemen Resiko (Studi Empiris Perusahaan Manufaktur Yang Go Publik). Skripsi. Surabaya: STIESIA

Sari, Fuji, 2013. Pengaruh Corporate Governance, Konsentrasi Kepemilikan dan Ukuran Perusahaan Terhadap Pengungkapan Enterprise Risk Management. (Studi Empiris pada Perusahaan Manufaktur yang Terdaftar di BEI Tahun 20102011).Skripsi. UNNES

Siregar, dkk.2014. Efek Entrenchment Dan Alignment Pemegang Saham Pengendali Pada Strategi Diversifikasi Dan Kinerja Perusahaan Dan Peran Corporate
Governance.SNA 14. Lombok:

Universitas Mataram. September

Sri Utami dan Sawitri Dwi Prastiti. 2011. Pengaruh Karakteristik Perusahaan Terhadap Social Disclosure. Dalam Jurnal Ekonomi Bisnis, 16(1): h: 63-70

Soewardjono. 2005. Teori Akuntansi. Edisi 3. Yogyakarta :BPFE

Suripto, Bambang, 1999, "Pengaruh Karakteristik Perusahaan erhadap Luas Pengungkapan Sukarela Dalam Laporan Tahunan, Simposium Nasional Akuntansi II IAIKAPd

Suwardjono. 2008. Teori Akuntansi Perekayasaan Pelaporan Keuangan. Yogyakarta : BPFE

Subiyantoro, Edi. 1996. Hubungan Antara Kelengkapan Pengungkapan Laporan Dengan Karakteristik Perusahaan Publik Di Indonesia. Tesis. Universitas Gajah Mada.

Sudarmadji, Ardi Murdoko dan Sularto. 2007. Pengaruh Ukuran Perusahaan, Profitabilitas, Leverage, dan Tipe Kepemilikan Perusahaan Terhadap Luas Voluntary Disclosure Laporan Keuangan Tahunan. Vol 2, ISSN : 1858-2559.

Suhardjanto, Djoko dan Aryane Dewi. 2011. Pengungkapan Risiko Finansial dan Tata Kelola Perusahaan : Studi Empiris Perbankan Indonesia.Jurnal Keuangan dan Perbankan. Vol. 15 No. 1 Januari 2011, hlm. 105-118.

Taures, Nazila Sofi Istna, 2011. Analisis Hubungan Antara Karakteeristik Perusahaan Dengan Pengungkapan Risiko: Studi Empiris pada Laporan Tahunan Perusahaan-Perusahaan NonKeuangan yang Terdaftar di BEI Tahun 2009. Skripsi. Semarang: Fakultas Ekonomi Universitas Diponegoro

Umar, Husein. 2001. Manajemen Risiko Bisnis Pendekatan Finansial dan Non 
Finansial. Jakarta: Gramedia Pustaka Utama

Wahidahwati. 2002. Pengaruh Kepemilikan Manajerial dan Kepemilikan Institusional pada Kebijakan Hutang Perusahaan: Sebuah Perspektif Theory Agency. Jurnal Riset Akuntansi Indonesia Vol. 5 No. 1. Ikatan Akuntan Indonesia-Kompartemen Akuntan Pendidik Yogyakarta

Wardani, Puruwita. 2012. Faktor - Faktot yang Mempengaruhi Luas Pengungkapa Sukarela. Jurnal Akutansi dan Keuagan. Vol 14 No 1. Mei ; 1-15
Weston, J Fred dan Eugene F Brigham . 1990. Dasar-Dasar Manajemen Keuangan Jilid 2 edisi Kesembilan. Jakarta : Erlangga

Widodo, Nova. 2014. Pengaruh Karakteristik Perusahaan terhadap Pengungkapan Akuntansi Sumber Daya Manusia. SNA 17 Mataram.

Zen, Sr Daryanti. 2007. Pengaruh Harga Saham, Umur Perusahaan dan Rasio Profitabilitas Perusahaan Terhadap Tindakan Perataan laba yang dilakukan oleh Perusahaan yang Terdaftar di Bursa Efek Jakarta. Jurnal Akuntansi dan Manajemen. Vol 2 No 2. ISSN 1858-36 